九州大学学術情報リポジトリ

Kyushu University Institutional Repository

\title{
Serodiagnosis of Viruses Infecting Some Crops of Bangladesh
}

Akanda, Abdul Mannan

Laboratory of Plant Pathology, Faculty of Agriculture, Kyushu University

Tsuno, Kazunori

Laboratory of Plant Pathology, Faculty of Agriculture, Kyushu University

Wakimoto, Satoshi

Laboratory of Plant Pathology, Faculty of Agriculture, Kyushu University

https://doi.org/10.5109/23958

出版情報 : 九州大学大学院農学研究院紀要. 35 (3/4)，pp.121-129，1991-02. Kyushu University バージョン：

権利関係 : 


\title{
Serodiagnosis of Viruses Infecting Some Crops of Bangladesh
}

\author{
Abdul Mannan Akanda, Kazunori Tsuno and Satoshi W akimoto \\ Laboratory of Plant Pathology \\ Faculty of Agriculture, Kyushu University, Fukuoka 812, Japan \\ (O ctober 15, 1990)
}

\begin{abstract}
As many as 39 plant samples representing nine different botanical families, showing symptoms like virus diseases, were collected from different locations of Bangladesh in 1986-87. The samples were preserved at $4^{\circ} \mathrm{C}$ after drying by lyophilization or over calcium chloride. Double antibody sandwich enzyme-linked immunosorbent assay (DAS-ELISA) and dot-immunobinding assay (DIBA) were applied for serological detection of viruses by using 11 different antiivirus-sera. Many of the samples $(28 / 39)$ showed positive reaction with either of the antisera used. In all eight different viruses, such as tobacco mosaic virus-ordinary strain (TMV-OM), turnip mosaic virus (TuMV), broad bean wilt virus (BBWV), Shallot latent virus (SLV), leek yellow stripe virus (LYSV), tobacco rattle virus (TRV), papaya ringspot virus (PRSV) and mungbean yellow mosaic virus (MYMV) were serologically detected. Among these, mixed infection of SLV and LYSV were detected from garlic sample. Mixed infection of TuMV and BBWV were also detected from the sample of Chinese cabbage. TMV-OM were found to be common in various plant species while PRSV, TuMV, TRV, MYMV and both SLV and LYSV were detected from each of papaya, Chinese cabbage, lettuce, okra and garlic samples, respectively. The results suggest that the dried samples stored for 2-3 years retained antigenicity of the viruses which could be detected by serological methods like DIBA and DAS-ELISA.
\end{abstract}

\section{INTRODUCTION}

The catastrophy of plant virus diseases on various crops throughout the world has been well-recognized as one of the major constraints of yield and quality of various crops (Gibbs and Harrison, 1979 ; Gonsalves, 1989 ; Kajiwara and Konno, 1986 ; Meiners, 1981 ; Nene, 1988). So far, more than one viruses have also been reported to damage in each crop in the tropical south east asian countries (Kajiwara and Konno, 1986 ; Yora et al. 1983 ; TARC, 1977).

Many varieties of crops other than major cereals, legumes, cucurbits, solanaceous plants etc. are cultivated in Bangladesh. These are mainly fiber, fruit and vegetable crops such as jute, cotton, papaya, cabbage, cauliflower etc. and considered to be economically important there (Alim, 1974 ; Rabbani, 1984 ; Rashid, 1976). The tropical-hot-humid climate is thought to be one of the main cause to favour the havoc of plant diseases in Bangladesh (Fakir, 1984). Ahmed (1984) reported that among the diseases of crops, those caused by viruses have been observed to be high in prevalence on the basis of the symptom expression in the field. Although, the identification of the causal agents of these diseases have not yet been done due to lack of research facilities and trained manpower for proper investigation on plant viruses in Bangladesh until now. However, the identification of plant viruses causing damage to the individual crops is highly important to combat the diseases. Therefore, the present study was 
undertaken for serological detection of viruses infecting some crops in Bangladesh.

\section{MTAERIALS AND METHODS}

\section{Sample collection and preservation}

In all 39 samples consisted of 13 different plant species representing nine botanical families were collected from various locations of five different adminstrative districts of Bangladesh in 1986-87 (Table 1). Fresh leaves of infected plants showing virus disease-like symptoms were collected in polyethylene bags. Immediately after collection the samples were processed for drying either by lyophilization or over calcium chloride as described by Hill (1988) and stored at $4^{\circ} \mathrm{C}$ until use.

\section{Inoculation test}

All the samples were inoculated to the original host plants and also to some commonly used local lesion hosts such as Chenopodium quinoa, C. amaraticolor, Pisum sativum, Phaseolus vulgaris, Cucumis sativum, Nicotiana glutinosa, N. tabacuvn and Gomphrenaglobosa following the method described by Noordam (1973). The inoculation was done in a temperature controlled greenhouse $\left(20 \sim 25^{\circ} \mathrm{C}\right)$.

\section{Antisera}

Polyclonal rabbit antisera of CMV-Y (cucumber mosaic virus-serotype Y), TMVOM (tobacco mosaic virus-ordinary strain), TuMV (turnip mosaic virus), BBWV (broad bean wilt virus), SLV (shallot latent virus), LYSV (leek yellow stripe Virus), TRV (tobacco rattle virus), AMV (alfalfa mosaic virus), MYMV (mungbean yellow mosaic virus), PRSV-W (papaya ringspot virus-watermelon strain) and PRSV-P (PRSV-papaya strain) were used in the experiments. Antisera of TMV-OM, TuMV, SLV and LYSV were provided by Dr. T. Maeda, Okayama University, Japan. The antisera against BBWV, TRV and AMV were provided by Dr. M. Kameya, National Agriculture Research Center, Tsukuba, Japan, those of PRSV-W and PRSV-P were supplied by Dr. N. Sako of Saga University, Japan and Dr. D. Gonsalves of Cornell University, USA, respectively.

Double antibody sandwich enzyme-linked immunosorbent assay (DAS-ELISA)

Purified y-globulin of PRSV-W and the y-globulin conjugated with alkaline phophatase used in the experiment were provided by Dr. N. Sako. DAS-ELISA was done as the principles described by Clark and Adams (1977) with simple modifications. y-globulin was diluted $(2 \mu \mathrm{g} / \mathrm{ml})$ in $0.05 \mathrm{M}$ carbonate buffer containing $0.02 \%$ sodium azide ( $\mathrm{pH}$ 9.6). An amount of $200 \mu \mathrm{l}$ diluted y-globulin was poured in each well of microtiter plates (Nunc, Denmark) and incubated at $37^{\circ} \mathrm{C}$ for $3 \mathrm{hr}$. Homogenate of the samples was prepared by macerating a small amount (ca. $0.05 \mathrm{~g}$ ) of dried sample on a Parafilm in a few drops of PBS $(0.02 \mathrm{M}$ phosphate buffer, $0.15 \mathrm{M} \mathrm{NaCl}, 0.02 \%$ sodium azide, pH 7.4 containing $0.05 \%$ Tween 20 and $2 \%$ polyvinylpyrrolidone ; PVP : Av. Mol. Wt. 40,000). Aliquot was pourd at the rate of $30 \mu \mathrm{l} /$ well containing $120 \mu \mathrm{l}$ sample buffer (PBS-Tween-PVP) and incubated overnight at $4{ }^{\circ} \mathrm{C}$. Enzyme conjugated $\gamma^{-}$ globulin was applied at $1: 1,000$ dilution in PBS-Tween-PVP containing $2 \%$ bovine serum albumin (BSA). After adding conjugated $\mathrm{y}$-globulin $(100 \mu \mathrm{l} /$ well), the plates 
Table 1. List of plant samples collected in Bangladesh.

\begin{tabular}{|c|c|c|}
\hline Plant samples & Symptom & Location \\
\hline \multicolumn{3}{|l|}{ CARICACEAE } \\
\hline *1. Рарауа & Fern leaf & Kashimpur, Gazipur \\
\hline *2. Р арауа & Mosaic & Joydebpur, Gazipur \\
\hline *3. Рарауа & Fern leaf & Kashimpur, Gazipur \\
\hline 4. Papaya & Mosaic & Kashimpur, Gazipur \\
\hline *5. Papaya & Vein-clearing & Salna, Gazipur \\
\hline *6. Рарауа & Mosaic & Patuakhali, Patuakhali \\
\hline 7. Papaya & Mosaic & Salna, Gazipur \\
\hline $\begin{array}{l}\text { *8. Papay a } \\
\text { CRUCIFERAE }\end{array}$ & Mosaic & Kashimpur, Gazipur \\
\hline 9. Cauliflower & Mosaic & Salna, Gazipur \\
\hline 10. Chinese cabbage & Mosaic & Kashimpur, Gazipur \\
\hline 12. Chinese cabbage & Yellowing & Kashimpur, Gazipur \\
\hline 13. Chinese cabbage & Curl & Kashimpur, Gazipur \\
\hline 14. Chinese cabbage & Chlorosis & Kashimpur, Gazipur \\
\hline 15. Chinese cabbage & Mosaic & Kashimpur, Gazipur \\
\hline 16. Chinese cabbage & Mosaic & Kashimpur, Gazipur \\
\hline 17. Chinese cabbage & Yellowing & Kashimpur, Gazipur \\
\hline $\begin{array}{l}\text { 18. Kadish } \\
\text { MALVACEAE }\end{array}$ & Mosaic & Salna, Gazipur \\
\hline 19. Cotton & Mosaic & Basherhat, Dinajpur \\
\hline 20. Cotton & Vein-clearing & Rasherhat, Dinajpur \\
\hline 21. Cotton & Chlorosis & Basherhat, Dinajpur \\
\hline 22. Cotton & Chlorosis & Basherhat, Dinajpur \\
\hline 23. Okra & Mosaic & Kashimpur, Gazipur \\
\hline 24. Okra & Mosaic & Kashimpur, Gazipur \\
\hline 25. Okra & Mosaic & Kashimpur, Gazipur \\
\hline 26. Okra & Mosaic, Vein-clearing & Salna, Gazipur \\
\hline 27. Okra & Vein-clearing & Salna, Gazipur \\
\hline 28. Okra & Mosaic & Rahmatpur, Barisal \\
\hline 29. Okra & Mosaic & Salna, Gazipur \\
\hline TILIACEAE & & \\
\hline 30. Jute & Mosaic & Ragunathpur, Jamalpur \\
\hline 31. Jute & Vein-clearing & Ragunathpur, Jamalpur \\
\hline $\begin{array}{l}\text { 32. Jute } \\
\text { ARACEAE }\end{array}$ & Mosaic & Charpolisha, Jamalpur \\
\hline 33. Colocasiu sp. & Vein-clearing & Ragunathpur, Jamalpur \\
\hline $\begin{array}{l}\text { 34. Colocasiu sp. } \\
\text { UMBELLIFERAE }\end{array}$ & Mosaic & Salna, Gazipur \\
\hline 35. Carrot & Necrosis & Kashimpur, Gazipur \\
\hline $\begin{array}{l}\text { 36. Coriander } \\
\text { COMPOSITAE }\end{array}$ & Necrosis & Joydebpur, Gazipur \\
\hline $\begin{array}{l}\text { 37. Lettuce } \\
\text { LILIACEAE }\end{array}$ & Chlorosis & Kashimpur, Gazipur \\
\hline $\begin{array}{l}\text { 38. Garlic } \\
\text { ASTERACEAE }\end{array}$ & Mosaic & Joydebpur, Gazipur \\
\hline 39. Safflower & Mosaic & Joydebpur, Gazipur \\
\hline
\end{tabular}

le infective in inoculation test. 
Table 2. Detection of viruses from samples of various crops of Bangladesh by DAS-ELISA and DIBA."

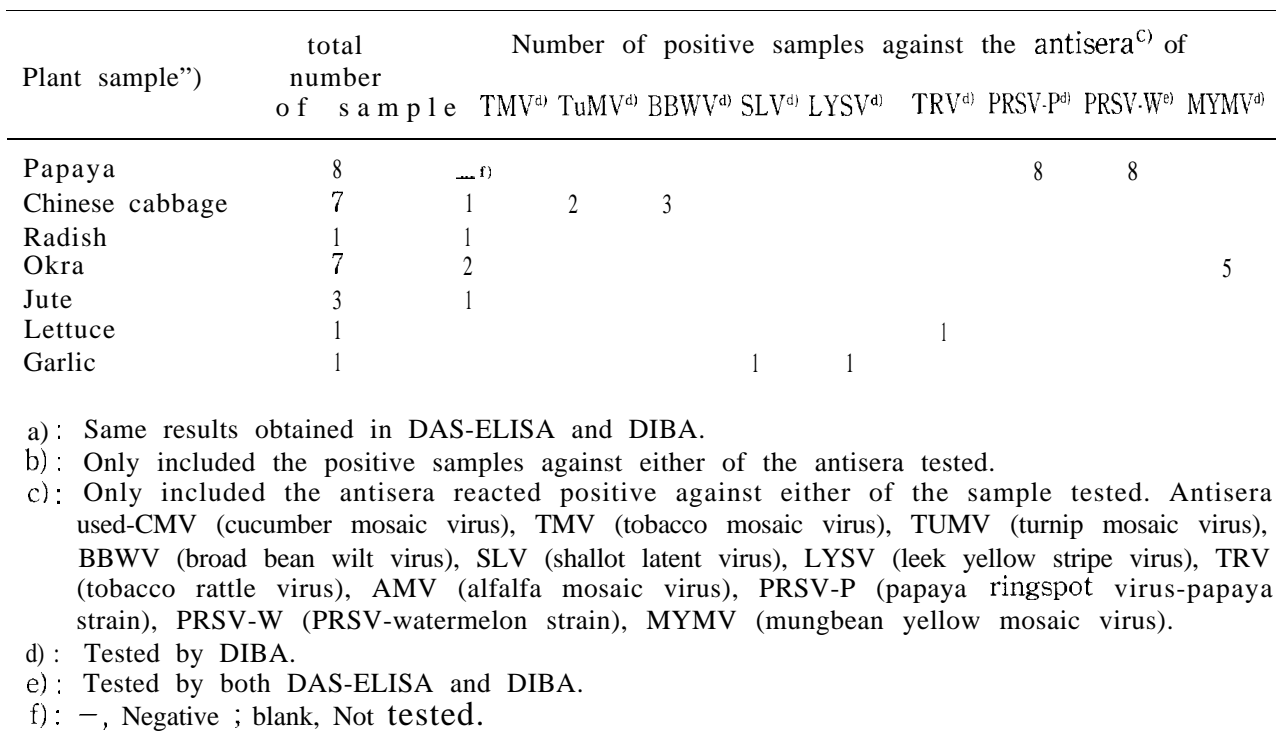

were incubated at $37^{\circ} \mathrm{C}$ for $3 \mathrm{hr}$. An amount of $100 \mu \mathrm{l}$ of substrate (p-nitrophenyl phosphate, $1 \mathrm{mg} / \mathrm{ml}$ of $10 \%$ diethanolamine, $\mathrm{pH} 9.6$ ) was applied and incubated at $30^{\circ} \mathrm{C}$ for $1 \mathrm{hr}$. Reaction was stopped by adding $50 \mu \mathrm{l}$ of $3 \mathrm{~N} \mathrm{NaOH}$ per well. Unless otherwise stated, the microtiter plates were washed with PBS-Tween 20 at least four times after each incubation. The absorbance values were measured by using ELISA analyser (Immuno Reader NJ-2000) at $405 \mathrm{~nm}$ wavelength.

\section{Dot -immunobinding assay (DIBA)}

DIBA was conducted as the principles developed by Hibi and Saito (1985) with slight modifications. Nitrocellulose membrane (NCM, Bio Rad) was cut into required size and marked with a grid of $0.75 \times \mathbf{0 . 7 5} \mathrm{cm}$ by a soft pencil and immersed in distilled water for $10 \mathrm{~min}$. NCM was then air dried on filter paper for $5 \mathrm{~min}$ and dotted with $2 \mu 1$ of sample extract prepared by macerating $0.05 \mathrm{~g}$ dried sample in a few drops (ca. $0.5 \mathrm{ml})$ of TBS (0.02 M Tris $-\mathrm{HCl}, 0.5 \mathrm{M} \mathrm{NaCl}, \mathrm{pH} 7.5)$ and dried for $15 \mathrm{~min}$. NCM was incubated in blocking solution consisted of $2 \%$ BSA and $2 \%$ Triton X-100 in TBS for $1 \mathrm{hr}$. Antiserum diluted $(1: 4,000)$ with healthy $1 \%$ leaf extract in TBST (TBS-0.05\% Tween 20) containing $0.2 \%$ BSA and $2 \%$ PVP was dotted on NCM at the rate of $20 \mu \mathrm{l} / \mathrm{grid}$ and incubated for $1 \mathrm{hr}$. Membrane was incubated with the conjugate diluted with TBST-BSA-PVP $(20 \mu \mathrm{l} /$ grid, $1: 8,000)$ for $1 \mathrm{hr}$ and then reacted with color development solution for 30-60 min as described by Banttari and Goodwin (1984). Unless otherwise stated, NCM was washed in TBST at least three times after each incubation. All experiments were carried out at room temperature and in plastic Petri dish. 


\section{RESULTS}

\section{Inoculation test}

Six papaya samples (marked with asterisk in Table 1) out of eight were found to be infective and produced mosaic sympton on the leaves of papaya within 10 days after inoculation. The symptom was gradually transformed into severe distortion, veinclearing, vein-banding and shoe-string. Sap inoculation of all isolates from the infected papaya plants to some cucurbits like C. sativum, C. metuliferus, Lagenaria siceraria, Citrullus lanatus, C. quinoa, C. amaraticolor, G. globosa, N. glutinosa, N. tabacum a n d papaya showed that all the isolates could infect C. metulifenus and papaya only. All other samples were found to be non-infective in repeated inoculation to the original host plants as well as to those expected to be the local lesion host.

\section{DAS-ELISA and DIBA}

DAS-ELISA was conducted only for papaya samples using antibodies of PRSVW. As shown in Table 2, all the eight papaya samples were found to be positive. Although dried samples were used in the experiment, the problem of non-specific reactions did not appear.

All the samples were tested by DIBA and the results are summarized in Table 2 . All the 8 papaya samples positive in DAS-ELISA were also found to be positive against both PRSV-W and PRSV-P antisera. TMV, TuMV and BBWV were detected from one, two and three samples in Chinese cabbage, respectively. One samples of Chinese cabbage was found to be positive against both TuMV and BBWV antisera. TMV was also detected from one radish, two okra and one jute samples. Lettuce sample was found to be positive against TRV antiserum. Garlic sample was detected as mixedly infected with LYSV and SLV. The okra samples were reacted positively against the antisera of MYMV and TMV. None of the samples were found to be positive against CMV antiserum. Development of distinct purple red color on the NCM was graded as positive reaction in DIBA.

\section{DISCUSSION}

In this experiment, sample of each plant species were tested against anti-virus-sera of the viruses which have been reported to be naturally prevalent on those particular plant species (deBox, 1981 ; Franki et al., 1979 ; Harrison, 1970 ; Jaspars and Bos, 1980 ; Taylor, 1972 ; Tomlinson, 1970 ; Yora et al., 1983 ; Zaitlin and Israel, 1975). We requested for the antisera of several viruses to many laboratories in Japan and abroad considering, the samples available to us. Therefore, the experiment was conducted without some important anti-virus-sera causing an unavoidable limitation in this study. However, the results of this study suggest the occurrence of eight different viruses from various crops of Bangladesh.

All the papaya samples reacted positively against PRSV antiserum. PRSV has been reported to be a papya strain of watermelon mosaic virus (WMV) causing severe damage to the crop in all papaya growing areas (Gonsaves et al., 1984). Ahmed (1984) reported that about $100 \%$ papaya plants have been found to be naturally infected producing symptoms similar to PRSV-P irrespective of varieties, regions and seasons 
in Bangladesh. We also observed the same situations during sampling. In our study, the papaya isolates failed to infect cucurbits and Chenopodium tested according to the method described by Yeh and Gonsalves (1984). This fact may support the results of Quiot-Douine et al. (1990) who reported the existence of differences within PRSV-P in relation to host range. No serological differences were observed between PRSV-P and PRSV-W which support the previous report (Gonsalves et al., 1984).

About $100 \%$ okra plants showed severe yellowing symptom in some fields. The infected plants produce dwarf and distorted fruits. This disease has been considered to be the threat of okra production in Bangladesh (Ahmed, 1984). Out of seven okra samples, MYMV and TMV-OM were detected from five and two okra samples, respectively. MYMV is a white fly transmitted geminivirus which has been reported to naturally infect the plants of Malvaceae (Bird and Maramorosch, 1978 ; Goodman, 1981 ; Thongmeearkom, et al., 1981). In our serological test, the results proved that the severe disease of okra in Bangladesh may be caused by virus of gemini group.

Many researchers reported the mixed infection of garlic with SLV and LYSV (Bos et al., 1978a ; Bos et al., 1978b ; Lee et al., 1979). Results of this study support the previous reports. In Bangladesh, garlic is grown from bulbs and observed to be gradually degenerating to smaller in size. In our observation, during sampling, about $100 \%$ plants were found to be infected in the field. The use of bulbs infected with SLV and LYSV may be one of the major cause of size degeneration.

Among the other detected viruses, TMV was found to be distributed to several plants like Chinese cabbabe, radish, okra and jute. TuMV and BBWV were confined to Chinese cabbage while TRV was detected from lettuce only.

The superiority of DAS-ELISA as a serological method compared to any others was reported by Clark (1981), Clark and Bar-Joseph (1984) and Clement et al.(1986). Although, we used the dried samples most of which were found to be lost their infectivity during the 2-3 years of storage, the results of our study demonstrated that both DAS-ELISA and DIBA were equally useful for detecting viruses from the dried samples without any difficulties which were previously reported by Ozyanar and Sako (1987). Generally, the appearance of non-specific reaction has been reported to be the only problem in immunoassy by DIBA (Banttari and Goodwin, 1984 ; Lizarraga and Fernandez-Northcote, 1984). Preliminary absorbtion of antisera with $1 \%$ healthy leaf extract of propagation host could successfully eliminate this problem.

Inoculation test proved inactivation of the viruses in most of the samples during storage. Some researchers reported that the stability of the viruses in storage depends on many factors such as drying method, host plants, storage conditions etc. (McKinney et al., 1965 ;McKinny and Silber, 1968). PRSV was found to be stable as compared to others. In our case, prolonged insufficient storage conditions including the drastic change of temperature conditions during transportation of the samples from Bangladesh to Japan might be one of the reasons of inactivation of the viruses. However, we could serologically detect MYMV in okra sample of Bangladesh which has been reported to be non-transmissible or very difficult to inoculate by mechanical method (Goodman, 1981).

Our results suggest that the antigenicity of the viruses retains for long period (23 years) under dried conditions even after the loss of infectivity. The informations obtained in this experiment may be useful in intensive survey program for plant virus 
diseases in a large area. Although, the serological similarity of the virus does not necessarily mean the complete identity in all properties of all the viruses. Further detailed studies on each viruses should be emphasized. However, the results of this study reveal the immediate necessity of launching virus disease research in Bangladesh.

\section{ACKNOWLEDGEMENT}

We with to thanks to Dr. Maeda, Okayama University ; Dr. M. Kameya, National Agriculture Research Center ; Dr. N. Sako, Saga University, Japan ; and Dr. D. Gonsalves, Cornell University, USA for generously providing antisera used in the experiments. We are grateful to Dr. N. Matsuyama, Plant Pathology Laboratory, Faculty of Agriculture, Kyushu University for his valuable discussions during experiments. Also thanks are due to Dr. T. Kawarabata, Faculty of Agriculture, Kyushu University who kindly allowed us to use the laboratory facilities for measuring ELISA values. We appreciate the kind help and cooperation of Dr. S. H. Khan, Director and Dr. I. H. Mian, Associate Professor, IPSA, Bangladesh, during sample collection in Bangladesh. Appreciations are also extended to JICA (Japan International Cooperation Agency)/ IPSA (Institute of Post-Graduate Studies in Agriculture) Project, Bangladesh, for cooperating with this research in Bangladesh.

\section{REFERENCES}

Ahmed, M. U. 1984 Diseases of vegetables and fruit trees in Bangladesh. A paper presented in the First Biennial Conference (held on December 13-14) of Bangladesh Phytopathological Society, 18 PP

Alim, A. 1974 An introduction to Bangladesh Agriculture. Swadesh Printing Press, Gopikishan Lane, Dhaka, Bangladesh, $432 \mathrm{pp}$

Banttari, E. E. and P. H. Goodwin 1985 Detection of potato virus S, X and Y by enzyme-linked immunosorbent assay on nitrocellulose membrane (DOT-ELISA). Plant Dis., $69: 202205$

Bird, J. and K. Maramorosch 1978 Viruses and virus diseases associated with whiteflies. $A d v$. virus Res., 22: $55^{-110}$

Bos, L., N. Huijberts, H. Huttinga and D. Z. Maat 1978a Leek yellow stripe virus and its relationships to onion yellow dwarf virus ; characterization, ecology and possible control. Neth.J. PI. Path., $84: 185-204$

Bos, L., H. Huttinga and D. Z. Maat 1978b Shallot latent virus, a new carlavirus. Neth. J.Pl. Path., $84: 227-237$

Clark, M. F. 1981 Immunosorbent assays in plant pathology. Ann. Rev. Phytopath., 19: 83-106

Clark, M. F. and A. N. Adams 1977 Characteristics of microplate method of enzyme-linked immnosorbent assay fot the detection of plant viruses. J. Gen. Virol., 34: 475-483

Clark, M. F. and M. Bar-Joseph 1984 Enzyme immunosorbent assays in plant viroloy. Meth. Virol., 7: $51-85$

Clement, D. L., R. M. Lister and L. E. Foster 1986 ELISA-based studies on the ecology and epidemiology of barley yellow dwarf virus in Indiana. Phytopathology, $76: 86^{-92}$

Debox, J. A. 1981 Potato virus Y. CMI/AAB Description of Plant Viruses No. 242. CMI, Kew, Surry, England, $6 \mathrm{pp}$

Fakir, G. A. 1984 Plant disease problems of Bangladesh. A keynote papaer presented in the First Biennial Conference (held on December 13-14) of Bangladesh Phytopathological Society, 9 pp 
Franki, R. I. B., D. W. Mossop and T. Hatta 1979 Cucumber mosaic virus. CMI/AAB Description of Plant Viruses No. 213. CMI, Kew, Surry, England, 6 pp

Gibbs, A. and B. Harrison 1979 Plant Virology-The principles, First Edition. Edward Arnold Ltd., 292 PP

Gonsalves, D., J. Edwardson and E. Hiebert 1984 Papaya ringspot virus. CMI/AAB Description of Plant Viruses No. 292. CMI, Kew, Surry, England, 8 pp

Gonsalves, D. and S. M. Garnsey 1989 Cross-protection techniques for control of plant virus diaeases in the tropics. Plant. Dis., 73: 592-597

Goodman, R. M. 1981 Geminiviruses. J. Gen. Virol., 54: 9-21

Harrison, B. D. 1970 Tobacco rattle virus. CMI/AAB Description of Plant Viruses No. 12. CMI, Kew, Surry, England, $4 \mathrm{pp}$

Hibi, T. and Y. Saito 1985 A dot immunobinding assay of tobacco mosaic virus in infected tissues. $J$. Gen. Virol., 66: 1191-1194

Hill, S. A. 1984 Methods in Virology, Vol.1. Blackwell Scientific Publications, Oxford, London 167, pp

Jaspars, E. M. J. and L. Bos 1980 Alfalfa mosaic virus. CMI/AAB Description of Plant Viruses No. 229. CMI, Kew, Surry, England, 6 pp

Kajiwara, T. and S. Konno (Eds) 1986 Virus diseases of rice and legumes in the tropics. Tech. Bull. Trop.Agri.Res.Cen. No. 21. TARC, Ibaraki, Japan, 238 pp

Lee, Y. W., S. Yamazaki, T. Osaki and T. Inoue 1979 Two elongated viruses in garlic, garlic latent virus and garlic mosaic virus. Ann. Phytopath. Soc. Japan, $45: 727-734$

Lizarraga, C. and E. N. Fernandez-Northcote 1989 Detection of potato virus X and $\mathrm{Y}$ in sap extracts by a modified indirect enzyme-linked immunosorbent assay on nitrocellulose membranes (NCM ELISA). Plant Dis., 73: 11-14

McKinny, H. H. and G. Silber 1968 Methods of preservation and storage of plant viruses. Meth.Virol., 4: $491-501$

McKinny, H. H., G. Silber and L. W. Greeley 1965 Longevity of some plant viruses stored in chemically dehydrated tissues. Phytopathology, 55 : 1043-1044

Meiners, P. J., G. I. Mink and R. 0. Hampton 1981 Genetics of disease resistance in edible legumes. Ann. Rev. Phytopath., 21: 189-209

Nene, Y. L. 1988 Multiple-disease resistance in grain legumes. Ann. Rev. Phytopath., 26 :203-217

Noordam, D. 1973 Identification of Plant Viruses-methods and experiments. Center for Agrcultural Publishing and Documentation, Wageningen, the Netherlands, $207 \mathrm{pp}$

Ozyanara, F. and N. Sako 1987 The detection of cucumber mosaic virus by enzyme-linked immunosorbent assays. Bull. Fac. Agri., Saga Univ., $62: 109-115$

Quiot-douine, L., H. Lecoq, J. B. Quiot, M. Pitrat and G. Labonne 1990 Serological and biological variability of virus isolates related to strains of papaya ringspot virus. Phytopathology, 80:256 $-263$

Rabbani, A. K. M. G.(Ed.) 1984 Yearbook of Agricultural Statistics of Bangladesh. Govt. of People' s Republic of Bangladesh, Dhaka, Bangladesh, 505 pp

Rashid, M. M. 1976 Vegetables in Bangladesh (in Bengali). BARI, Joydebpur, Bangladesh, 494 pp

TARC 1977 Symposium of virus diseases of tropical crops. Trop.Agri. Res. Ser. No. 10. TARC, Ibaraki, Japan, $222 \mathrm{pp}$

Taylor, R. H. 1972 Broad bean wilt virus, CMI/AAB Description of Plant Viruses No. 81. CMI, Kew, Surry, England, 4 pp

Thongmeearkom, P., Y. Honda, Y. Saito and R. Syamananda 1981 Nuclear ultrastuctural changes and aggregates of virus-like particles in mungbean cells affected by mungbean yellow mosaic disease. Phytopathology, $71: 41-44$

Tomlinson, J. A. 1970 Turnip mosaic virus. CMI/AAB Description of Plant Viruses No. 8. CMI, Kew, Surry, England, 4 pp

Yeh. S. D. and D. Gonsalves 1984 Purification and immunological analysis of cylindrical-inclusion 
protein induced by papaya ringspot virus and watermelon mosaic virus 1. Phytopathology, 74: $1273-1278$

Yora, K., Y. Saito, Y. Doi, T. Inoue and K. Tomaru 1983 Dictionary of Plant Virus (Shokubutsu Virus Jiten). Asakura Shoten, Tokyo, Japan 632 pp

Zaitlin, M. and H. W. 1975 Israel Tobacco mosaic virus (Type strain). CMI/AAB Description of Plant Viruses No. 151. CMI, Kew, Surry, England, 5 pp 